Sigrid Schade

7 INTRODUCTION TO TURBULENCE AND RECONSTRUCTION

Jill Scott

\title{
ART AND SOCIETY
}

15 THE BIG GAP

Johanna Lier / With Photos by Nurit Sharett

29 IDENTIFYING AND CATEGORIZING: POWER, KNOWLEDGE, TRUTH AND

THE ARTISTIC STRATEGIES OF GUILLERMO GÓMEZ-PEÑA AND FIONA TAN

Teresa Chen

47 DEREALISATION, CINEMA AND THE TURBULENCE OF INFORMATION

Kit Wise

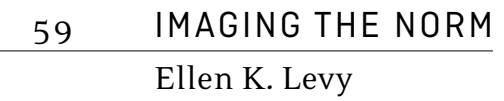

75 GALLERY A

\section{TURBULENCE}

CURATED BY SUSANNE N. HILLMAN

Dawn DeDeaux, Ziad Zitoun and George Osodi

\section{DESIGN AND ECOLOGY}

\begin{tabular}{cl}
91 & SUBSISTENCE FARMING - THE SURVIVAL STRATEGY \\
\hline & Angelika Hilbeck and Herbert Hilbeck \\
107 & UNCERTAINTY, UTOPIA, AND OUR CONTESTED FUTURE \\
\hline & Patrick Moriarty and Damon Honnery
\end{tabular}


121 REDESIGNING NATURE: SITUATING ART AND ECOLOGY

Christoph Kueffer and Jill Scott

139 TURBULENT SOCIETIES,

THE CHALLENGES OF DIGITAL CONTEMPORARY ARCHITECTURE

Jan Słyk

157

GALLERY B

INTERROGATING THE SUBLIME: RECONSTRUCTIONS

CURATED BY ANNA ACHTELIK

Tamiko Tiel, Josephine Starrs and Leon Cmielewski,

Eugenio Tisselli and Juanita Schlaepfer-Miller

\section{TECHNOLOGY AND SOCIETY}

\begin{tabular}{ll}
169 & RESILIENT SOCIETY \\
\hline & Agnieszka Jelewska \\
185 & EMPATHETIC THINGS \\
\hline & Juergen Moritz
\end{tabular}

201 PARANOIA AT PLAY: THE DARKEST PUZZLE AND THE ELEGANT TURBULENCE OF ALTERNATE REALITY GAMES

Hugh Davies and Vince Dziekan

217 ALTERNATIVE VISIONS: HUMAN FUTURES

Boris Magrini

BIOGRAPHIES

233 AUTHORS 
